Editorial

\title{
O volume 22 e as perspectivas futuras
}

\author{
Milton Artur Ruiz
}

Com este fascículo concluímos o volume 22

da Revista Brasileira de Hematologia e Hemoterapia. Foram editados ao longo do ano 2000, cinco fascículos sendo três regulares e dois suplementos referentes ao Congresso Brasileiro de Hematologia e Hemoterapia - Hemo 2000 (Abstracts e Programa Científico).

Neste volume a revista transformou-se também no órgão oficial da Sociedade Brasileira de Transplante de Medula Óssea, fato este que aumentou o espectro e a importância do veículo de comunicação. A amplitude de colaborações esteve presente com a edição de contribuições de todos os cantos do país, com temas diversos e contando com colaboradores que até então não haviam publicado na Revista Brasileira de Hematologia e Hemoterapia.

O formato da revista ao longo do ano foi mantido e o volume 22 teve um grande incremento com a edição do programa científico do Hemo 2000. Através do esforço da Comissão organizadora do Congresso, conjuntamente com a diretoria da Sociedade Brasileira de Hematologia e Hemoterapia, conseguimos recuperar, atualizar e editar um fascículo especial sobre os temas apresentados durante aquele evento comemorativo do cinquentenário da SBHH. Com a edição do suplemento especial, grande parte do temário científico foi perenizado e, sem sombra de dúvida, o mesmo será uma referência de consulta além de um exemplo a ser seguido pelas comissões dos futuros eventos científicos de Hematologia e Hemoterapia, que ocorrerão no país e certamente terão guarida e suporte deste veículo de comunicação.
Neste fascículo ressaltamos a publicação de dois artigos especiais de Hervé P. e colaboradores, sendo um deles objetivando o futuro e as perspectivas que se avizinham com novas abordagens terapêuticas e outro sobre como se processa a hemovigilância na França. Tais contribuições originalmente fariam parte do fascículo especial, pois haviam sido enviados para o Hemo 2000 sem terem feito parte do evento. Após análise pela comissão organizadora do evento o mesmo foi considerado de grande valor, portanto, não poderia deixar de abrilhantar as páginas da Revista Brasileira de Hematologia e Hemoterapia.

O fascículo em seu conteúdo apresenta diversas contribuições de importância com destaque para a área de hemoglobinopatias com artigos e uma carta ao editor sobre aborto em portadoras do traço siclêmico. A oncohematologia e o TMO também estão espelhados nas páginas da revista transformando este fascículo no mais heterogêneo possível, para atender a toda comunidade hematológica.

Nos próximos fascículos serão estimuladas novas seções e envidados esforços para que resumos de teses que ocorram no país sejam logo divulgados nas páginas da RBHH para que as contribuições dos jovens recém-graduados nos cursos de pósgraduação da área de hematologia ou correlatas sejam conhecidos de toda a comunidade.

No próximo ano o objetivo da Sociedade Brasileira de Hematologia e Hemoterapia e da Sociedade Brasileira de Transplante de Medula Óssea será o de solidificar a RBHH, cadastrandoa em outros bancos de dados e incluindo a mesma em outros índices de referência com a finalidade de disseminar e internacionalizar a revista.

Revista Brasileira de Hematologia e Hemoterapia Editor Científico 